\title{
Arsenic inhibits in vitro spermatogenesis and induces germ cell apoptosis in Japanese eel (Anguilla japonica)
}

\author{
Fritzie T Celino, Sonoko Yamaguchi, Chiemi Miura and Takeshi Miura \\ Research Group for Reproductive Physiology, South Ehime Fisheries Research Center, Ehime University, 1289-1 \\ Funakoshi, Ainan 798-4292, Japan \\ Correspondence should be addressed to T Miura; Email: miutake@agr.ehime-u.ac.jp
}

\begin{abstract}
The precise mechanism and direct effects of arsenic on fish, particularly in reproduction, are not well clarified. The aim of this study is to investigate the direct influence of arsenic on fish spermatogenesis using the Japanese eel (Anguilla japonica) in vitro testicular organ culture system. Eel testicular fragments were cultured in vitro with 0.1-100 $\mu \mathrm{M}$ arsenic with or without human chorionic gonadotropin (hCG) for 6 or 15 days at $20^{\circ} \mathrm{C}$. Arsenic treatment provoked a dose-dependent inhibition of hCG-induced germ cell proliferation as revealed by 5 -bromo-2-deoxyuridine immunohistochemistry. Time-resolved fluorescent immunoassay showed that arsenic suppressed hCG-induced synthesis of 11-ketotestosterone (11-KT) in testicular fragments incubated with $0.0001-100 \mu \mathrm{M}$ arsenic and hCG for $18 \mathrm{~h}$. A $0.1 \mu \mathrm{M}(7 \mu \mathrm{g} / \mathrm{l})$ dose of arsenic which is lower than the World Health Organization drinking water quality guideline of $10 \mu \mathrm{g} / \mathrm{l}$ most effectively reduced 11-KT production. The hCG-induced synthesis of progesterone from pregnenolone was significantly inhibited by low

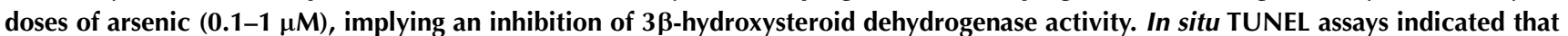
germ cells undergo apoptosis at the highest dose of arsenic $(100 \mu \mathrm{M})$. An arsenic concentration-dependent increase in oxidative DNA damage was detected by 8 -hydroxy-2'-deoxyguanosine $(8-\mathrm{OHdG})$ immunohistochemistry. A peak in 8-OHdG index was observed in testicular fragments treated with $100 \mu \mathrm{M}$ arsenic and hCG consistent with the TUNEL results. These data suggest that low doses of arsenic may inhibit spermatogenesis via steroidogenesis suppression, while high doses of arsenic induce oxidative stress-mediated germ cell apoptosis.
\end{abstract}

Reproduction (2009) 138 279-287

\section{Introduction}

Arsenic, a trace element ubiquitously present in the environment and one of the most significant pollutants of aquatic systems, has been widely known to cause deleterious effects to humans and wildlife. Inorganic arsenic contamination is a serious environmental problem worldwide due to the large number of contaminated sites that have been identified, particularly in Asia. Arsenic contamination in drinking water has become a significant concern in Bangladesh, West Bengal, India, China, Mongolia, Nepal, Cambodia, Myanmar, Afghanistan, DPR Korea, and Pakistan (Mukherjee et al. 2006). Arsenic has also been reported to contaminate marine environments (Kubota et al. 2002), freshwater environments (Cullen \& Reimer 1989), and groundwater (Alam et al. 2002).

Arsenic induces a broad range of effects including endocrine disruption (Kaltreider et al. 2001, Bodwell et al. 2006, Davey et al. 2007). Endocrine disruptors are defined as any substance that can interfere with normal hormone function. Chemicals that can act as endocrine disruptors, mimic or block function of normal hormones and trigger an abnormal response in cells include a number of either industrial, municipal, and agricultural chemicals released into the environment or naturally occurring compounds. The toxicity of arsenic as a potent endocrine disruptor has been extensively studied in mammals. It was reported that arsenic alters gene regulation by disruption of the closely related steroid hormone receptors for glucocorticoids, mineralocorticoids, progesterone, and androgen (Kaltreider et al. 2001, Bodwell et al. 2004, 2006) functions. However, studies pertaining to the precise mechanism of direct influence of arsenic on fish reproduction are very limited.

Fish reproduction has been considered to be a reliable indicator of endocrine disruption in aquatic systems by chemical compounds including arsenic. In the freshwater fish Colisa fasciatus (striped gourami), high doses of arsenic caused testicular abnormalities and impaired spermatogenesis in vivo (Shukla \& Pandey 1984). Arsenic is present in the environment as trivalent arsenite $(\mathrm{As}(\mathrm{III}))$ or pentavalent arsenate $(\mathrm{As}(\mathrm{V}))$. Of the two forms, $\mathrm{As}(\mathrm{V})$ typically dominates both in oxic sea and 
freshwater (Smedley \& Kinniburgh 2002, Duker et al. 2005); consequently, fish are likely to be exposed to As $(\mathrm{V})$. However, few studies described the toxicity of the less toxic form, $\mathrm{As}(\mathrm{V})$, on fish reproduction. A recent study in Mekong Delta of Vietnam has reported that there is a significant correlation between the gonadal morphology and development abnormalities, and accumulation of trace elements including arsenic in the liver of catfish, Pangasianodon hypophthalmus. It was also demonstrated that in vitro treatment of $\mathrm{As}(\mathrm{V})$ inhibited spermatogenesis in Japanese eel (Yamaguchi et al. 2007). However, the mechanism involved in the direct influence of arsenic on fish spermatogenesis is not yet well clarified.

In this study, the direct effects and toxic mechanisms of arsenic, in the pentavalent form, on fish spermatogenesis were examined using the Japanese eel testicular organ culture system. In Japanese eel, spermatogenesis could be induced by human chorionic gonadotropin (hCG) injection in vivo or treatment with 11-ketotestosterone (11-KT, a fish-specific androgen derived from testosterone) or hCG in vitro. In vertebrates, this is the only system available for the induction of complete spermatogenesis in vitro from spermatogonial proliferation to spermiogenesis (Miura et al. 1991a). Various factors that play important roles in fish spermatogenesis, have been identified using this method (Miura et al. 2006, Ozaki et al. 2006). Moreover, this system has been used to study the effects of pollutants on fish spermatogenesis (Miura et al. 2005, Yamaguchi et al. 2007). Hence, this system is used for investigating the direct effects and toxic mechanisms of arsenic on fish spermatogenesis.

\section{Results}

\section{Effects of arsenic on spermatogenesis}

We analyzed the effects of arsenic on fish testis in vitro with or without hCG. Testicular fragments of the control group contained type A spermatogonia after 6 days of culture. The histological structure of testis of the control group and those cultured with hCG alone did not differ from each other (Fig. 1A and B). However, germ cells in testis treated with $100 \mu \mathrm{M}$ arsenic alone or with hCG exhibit cell death. Moreover, extensive cell death and fibrotic hypertrophy of interstitial tissue were observed in groups treated with $100 \mu \mathrm{M}$ arsenic and hCG compared with those treated with arsenic alone (Fig. 1C and D). There was no observed change in histological structure such as cell death, degeneration, or hypertrophy in testis exposed to $0.1-10 \mu \mathrm{M}$ of arsenic with or without hCG (data not shown).

The influence of arsenic on the progression of spermatogenesis analyzed by 5-bromo-2-deoxyuridine (BrdU) incorporation in germ cells is shown in Figs 2A-G and 3. After treatment with hCG, the number of proliferating germ cells increased after 6 days (Figs $2 \mathrm{~A}$ and $\mathrm{B}$
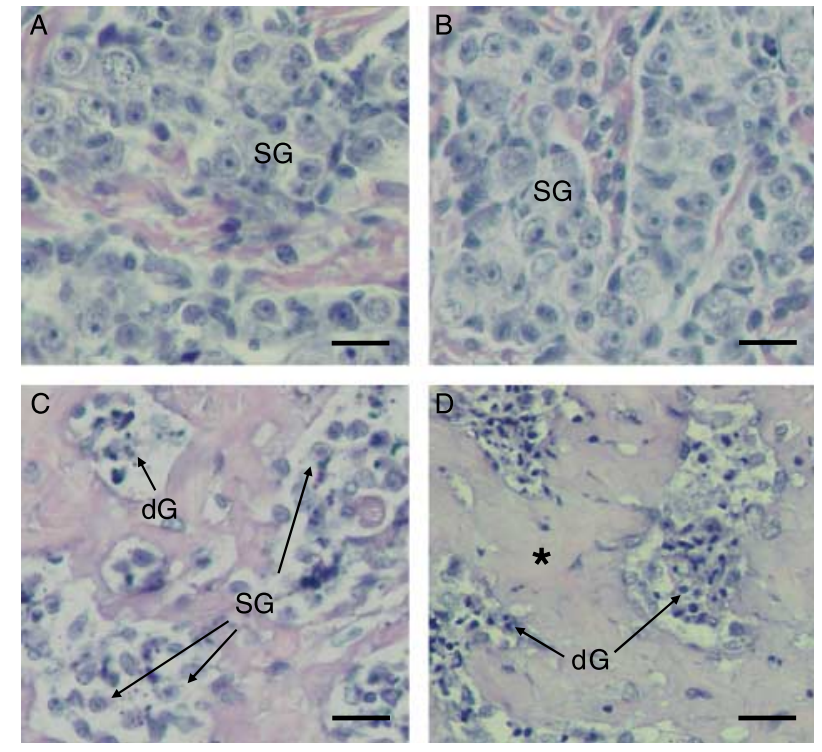

Figure 1 Representative light micrographs of Japanese eel testicular fragments cultured for 6 days. (A) Control (B) $0.05 \mathrm{IU} / \mathrm{ml}$ hCG. Normal morphology was observed with many spermatogonia. (C) $100 \mu \mathrm{M}$ arsenic. Some dead germ cells were observed. (D) $100 \mu \mathrm{M}$ arsenic with hCG. A notable increase in the number of dead germ cells was observed with fibrotic enlargement of interstitial tissue. dG, dead germ cells; SG, spermatogonia; *, enlarged interstitial tissue. Bars, $20 \mu \mathrm{m}$.

and $3 \mathrm{~A}$ ) and 15 days of culture (Fig. 3B). However, addition of arsenic significantly inhibited hCG-induced spermatogenesis in a dose-dependent manner (Figs $2 \mathrm{C}-\mathrm{F}$ and $3 \mathrm{~A}$ and $\mathrm{B})$. Even the lowest dose of arsenic $(0.1 \mu \mathrm{M})$ significantly inhibited hCG-induced germ cell proliferation $(P<0.05)$ in both 6 and 15 day-cultured testicular fragments (Figs $2 \mathrm{C}$ and $3 \mathrm{~A}$ and $\mathrm{B}$ ). In 15-day cultures treated with $100 \mu \mathrm{M}$ arsenic and hCG, not even a single BrdU-positive germ cell was detected due to extensive cell death (Figs 2G and 3B). Treatment with arsenic alone at lower doses $(0.1-10 \mu \mathrm{M})$ seemed to have no effect on germ cell proliferation both at 6 and 15 days of culture. However, at the highest dose of arsenic $(100 \mu \mathrm{M})$ alone, the number of BrdU-positive germ cell significantly decreased at 15 days of culture (data not shown).

\section{In vitro effects of arsenic on 11-KT synthesis and steroidogenic enzyme activity}

Figure 4 shows the effects of arsenic on 11-KT synthesis in hCG-activated testicular fragments of Japanese eel. The results showed that hCG induced 11-KT production in testis. Interestingly, arsenic inhibited hCG-induced $11-\mathrm{KT}$ synthesis in a dose-dependent manner. The most effective concentration of arsenic was $0.1 \mu \mathrm{M}$. However, while 11-KT level was significantly lower than the positive control (hCG alone-treated group) at one low dose $(0.1 \mu \mathrm{M})$, at the other higher arsenic doses used $(1-100 \mu \mathrm{M})$ there was no significant difference 

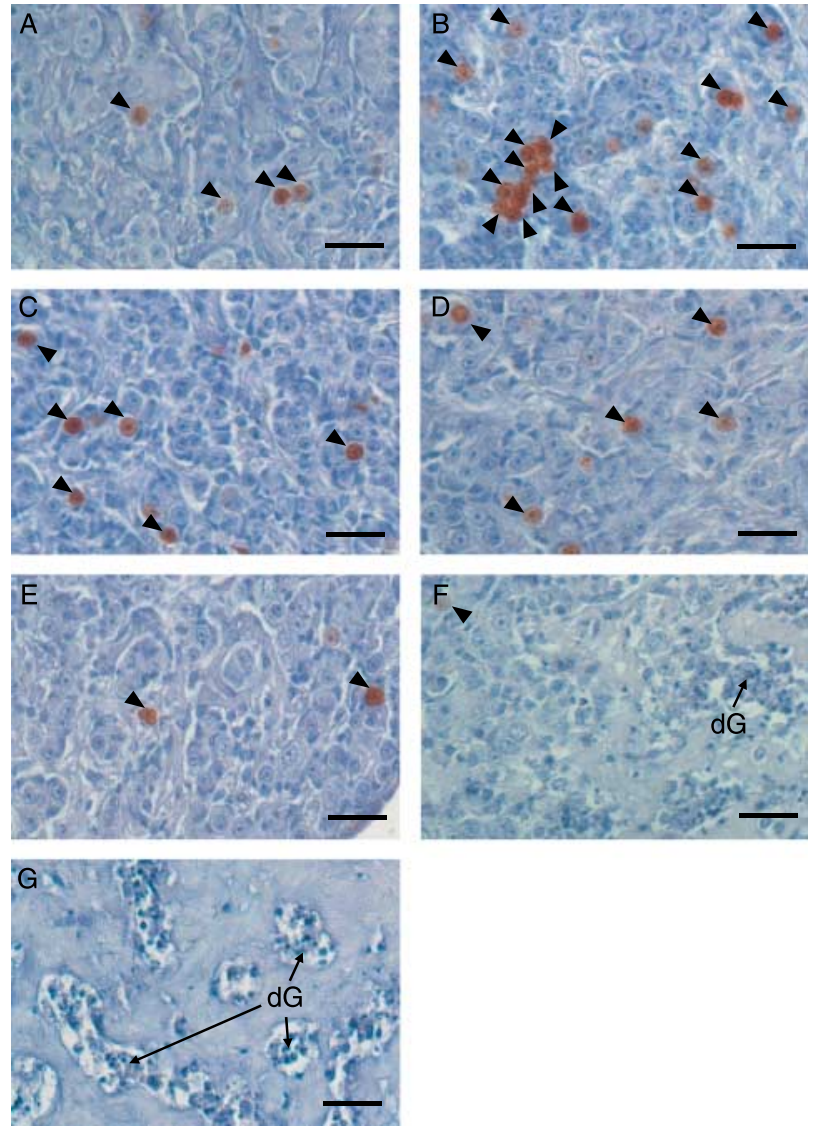

Figure $2 \mathrm{BrdU}$ immunohistochemistry in sections of eel testicular tissue cultured for 6 days in $0.1-100 \mu \mathrm{M}$ arsenic with hCG and 15 days in $100 \mu \mathrm{M}$ arsenic with hCG. Brown-stained cells are BrdU-positive cells (arrowheads). (A) Control (B) $0.05 \mathrm{IU} / \mathrm{ml}$ hCG. An increase in the number of proliferating germ cells was observed. Addition of arsenic in an increasing concentration of $0.1 \mu \mathrm{M}(\mathrm{C})$, $1 \mu \mathrm{M}(\mathrm{D}), 10 \mu \mathrm{M}(\mathrm{E})$, and $100 \mu \mathrm{M}(\mathrm{F})$ gradually decreased the number of proliferating germ cells induced by hCG and caused cell death at the highest dose. After 15 days of culture, no BrdU-positive germ cells were observed in group treated with $100 \mu \mathrm{M}$ arsenic and hCG (G). dG, dead germ cells. Bars, $20 \mu \mathrm{m}$.

compared with the positive control. To clarify the mechanism involved in 11-KT synthesis inhibition by arsenic, we analyzed the low-dose effect of arsenic on steroidogenic enzymes' activity. A considerable effect was observed on progesterone synthesis using pregnenolone as a precursor. A similar trend was observed to that of the low-dose arsenic effect on 11-KT synthesis in which at 0.1 and $1 \mu \mathrm{M}$ arsenic, progesterone level significantly decreased compared to the positive control (Fig. 5).

\section{Apoptosis of germ cells}

In order to determine whether arsenic-induced cell death is apoptosis or necrosis, TUNEL assay was conducted. The positive control group contained many TUNEL-positive cells, germ, and some somatic cells. In contrast, control group did not contain any
TUNEL-positive cell (Fig. 6A and B). In sections of testicular fragments treated with $100 \mu \mathrm{M}$ arsenic alone, a few germ cells showed positive reaction. On the other hand, in those treated with $100 \mu \mathrm{M}$ of arsenic and hCG, numerous germ cells exhibit positive signal compared with those treated with arsenic alone (Fig. 6C and D).

\section{Induction of oxidative stress by arsenic}

When cells are attacked by reactive oxygen species (ROS), DNA is oxidized, and deoxyguanosine, one of its constituents, is altered into 8-hydroxy-2'-deoxyguanosine $(8-\mathrm{OHdG})$. Hence, this $8-\mathrm{OHdG}$ is used as an indicator of oxidative damage in cells. Immunohistochemistry for $8-\mathrm{OHdG}$ revealed that control and hCGtreated testicular fragment sections were not stained (Fig. 7A and B). Whereas, testicular fragments incubated with arsenic and hCG showed strong signal and many intensely stained germ cells compared with those treated with arsenic alone (Fig. $7 \mathrm{C}$ and D). In addition, the densitometric quantitation of $8-\mathrm{OHdG}$ immunohistochemistry showed an increasing trend in $8-\mathrm{OHdG}$ index with increasing arsenic concentration both in arsenic alone and arsenic with hCG-treated groups. At arsenic concentration of $10 \mu \mathrm{M}$ with or without hCG, $8-\mathrm{OHdG}$ index was already significantly different from control $(P<0.05)$ and from hCG alone-treated group $(P<0.01)$ respectively. A peak in $8-\mathrm{OHdG}$ index $\left(7.5 \times 10^{3} \pm 2.9\right.$ $\times 10^{3}$ pixels/cell) was observed in the same treatment
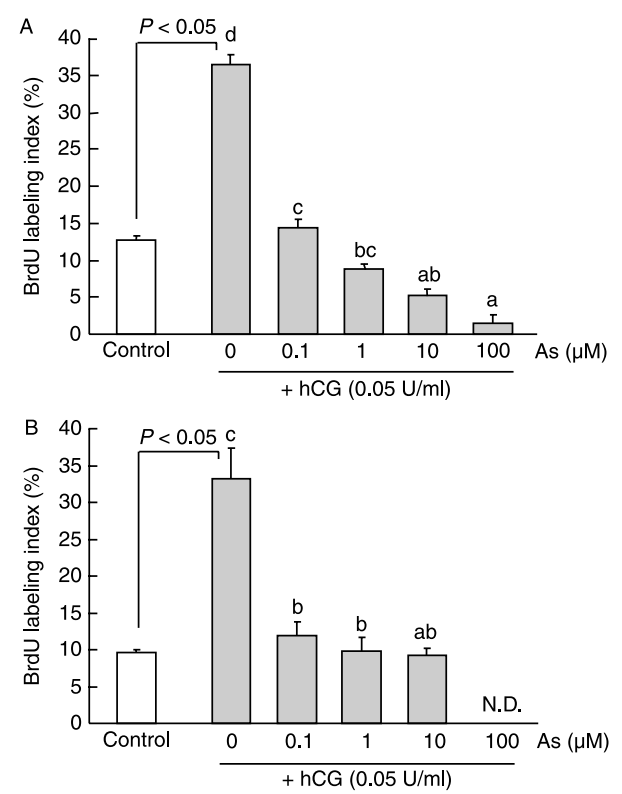

Figure 3 Effects of arsenic on hCG-induced germ cell proliferation in vitro (A) after 6 and (B) 15 days culture. Control, without arsenic and hCG. The number of positively immunoreacted germ cells is expressed as a percentage of the total number of germ cells. Values are means \pm S.E.M. $(n=5)$. Values with different letters are significantly different $(P<0.05)$. As, arsenic; N.D., BrdU-positive cells were not detected. 


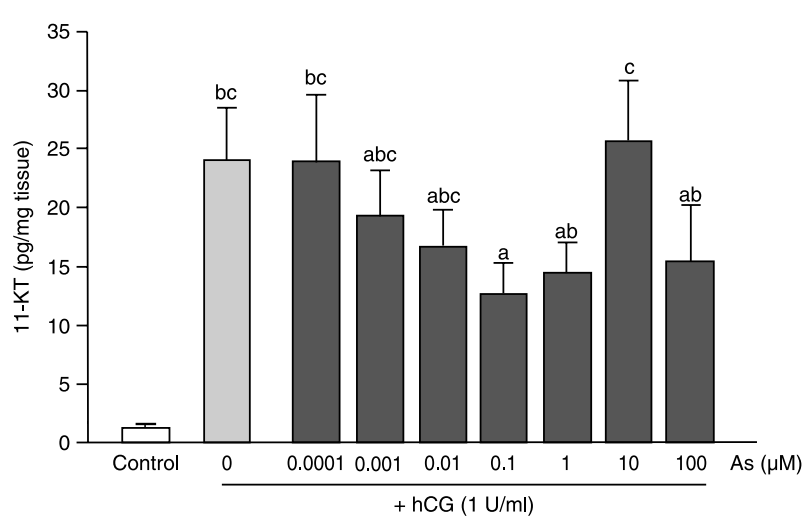

Figure 4 Effect of arsenic on hCG-induced 11-KT synthesis in vitro. Values are means \pm s.E.M. Values with different letters are significantly different $(P<0.05)$. Control, without arsenic and hCG; As, arsenic.

$(100 \mu \mathrm{M}$ arsenic and hCG) that strongly caused apoptosis. There was no significant difference between doses other than the highest concentration of arsenic and arsenic with hCG-treated groups except for $10 \mu \mathrm{M}$ arsenic $(P<0.05)$. Moreover, the $8-\mathrm{OHdG}$ index at the highest concentration of arsenic alone was significantly lower $(P<0.01)$ compared with those treated with arsenic and hCG (Fig. 8).

\section{Discussion}

Although previous data showed that there is a significant correlation between the alterations in histological structure and abnormalities in the development of testis, and accumulation of arsenic in collected fish (Yamaguchi et al. 2007), the biochemical basis of arsenic toxicity and the mechanism involved in this process are not yet fully understood. In the present study, we demonstrate that arsenic at high concentrations $(100 \mu \mathrm{M})$, alone or with hCG, causes degenerative

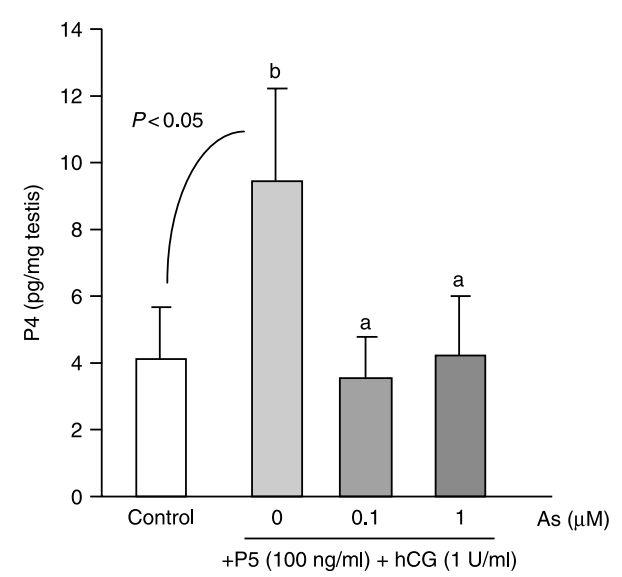

Figure 5 Effect of low-dose arsenic on hCG-induced progesterone (P4) synthesis from pregnenolone (P5) in vitro. Values are means \pm s.E.M. Values with different letters are significantly different $(P<0.05)$.

Control, without arsenic and hCG; As, arsenic. changes in eel testis and induces germ cell death in vitro in eel testis cultures. In groups cultured in arsenic with hCG, almost all testicular fragments died and exhibited severe enlargement of interstitial tissue. In previous studies, similar effects of arsenic have been reported. Alterations in testicular morphology, such as degenerative changes in the lobules, reduction in diameter of interstitial Leydig cells (steroid-secreting cells), necrosis, and pyknosis, were observed in the freshwater fish, C. fasciatus, following exposure to high doses of arsenic (Shukla \& Pandey 1984). Moreover, in an in vitro study using Japanese eel (Yamaguchi et al. 2007), treatment with high doses of arsenic and 11-KT, a major active androgen in teleosts (Borg 1994), induced cell death. To further analyze the influence of arsenic on spermatogenesis, we investigated the effects of arsenic on germ cell proliferation. Similar to previous studies (Miura et al. 1991a, 1991b), our study showed that hCG induced germ cell proliferation via 11-KT, as assessed by the BrdU index. Moreover, treatment with arsenic alone has no effect on germ cell proliferation except at the highest dose $(100 \mu \mathrm{M})$, which induced cell death, while treatment with arsenic and hCG significantly inhibited germ cell proliferation dose dependently. Furthermore, a low dose of arsenic $(0.1 \mu \mathrm{M})$, in the presence of hCG, already significantly suppressed germ cell proliferation. In mammals, reduced sperm count and motility after oral administration of sodium arsenite in mice (Pant et al. 2001) and early arrest of spermatogenesis after i.p. administration of sodium arsenite in rats (Ahmad et al. 2008) have been observed. Thus, previous published literature using in vivo experiments indicates that arsenic inhibits spermatogenesis similar to the conclusion of this in vitro work on the Japanese eel.

Previous in vitro studies by Miura et al. (1991b) and Ozaki et al. (2006) have revealed that eel testicular fragments produce 11-KT in response to hCG. Since $11-\mathrm{KT}$ is a major active androgen in teleost fish that initiates and maintains the progression of spermatogenesis through the action of Sertoli cells (Miura \& Miura 2003), we assumed that arsenic may exert its effect on spermatogenesis via 11-KT. To confirm the influence of arsenic on 11-KT production, we investigated the effects of arsenic on hCG-induced 11-KT synthesis in vitro. Our results showed that 11-KT synthesis was inhibited by treatment with arsenic, particularly at a low dose of $0.1 \mu \mathrm{M}(7 \mu \mathrm{g} / \mathrm{l})$ - a dose environmentally relevant and relatively lower than the World Health Organization guideline for drinking water quality $(10 \mu \mathrm{g} / \mathrm{l} ; \mathrm{WHO}$ 1996). This result suggested that low-level exposure to arsenic may inhibit spermatogenesis via inhibition of 11-KT synthesis. Sarkar et al. (1991) reported that injection of $\mathrm{As}(\mathrm{III})$ in rats resulted in the inhibition of $3 \beta$-hydroxysteroid dehydrogenase (HSD3B) and HSD17B activities in the testis. In our study, we examined whether inhibition of 11-KT synthesis by low-dose arsenic is mediated by inhibition of 


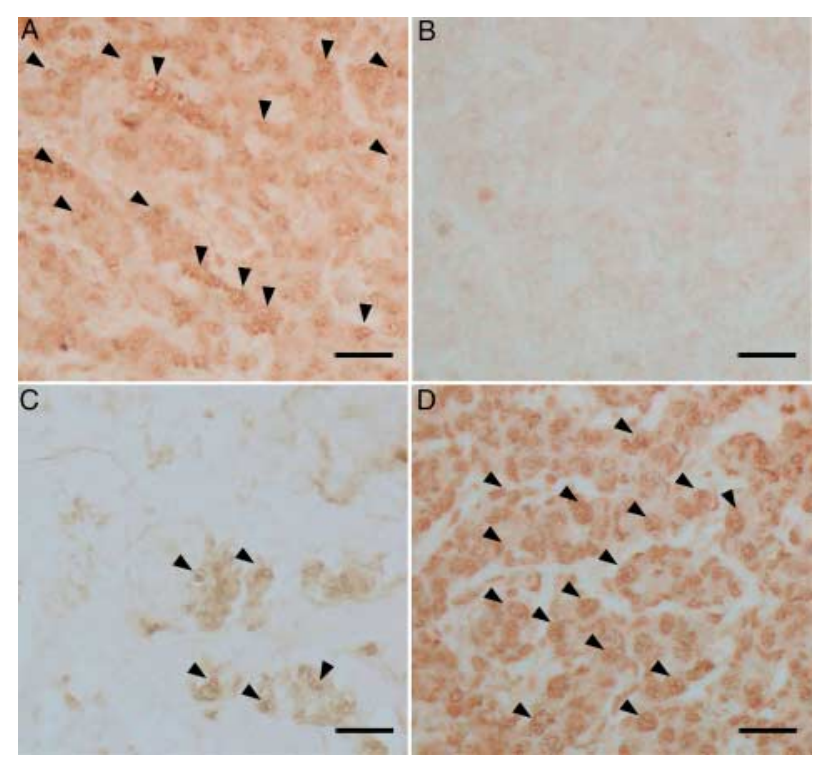

Figure 6 TUNEL assay in eel testicular tissue cultured for 3 days with $100 \mu \mathrm{M}$ arsenic alone or $100 \mu \mathrm{M}$ arsenic with hCG. Positively stained germ cells are indicated by arrowheads. (A) Positive control treated with DNAse before TUNEL. (B) Control. TUNEL-positive germ cells were not observed. (C) $100 \mu \mathrm{M}$ arsenic-treated group. Some TUNELpositive germ cells were observed. (D) $100 \mu \mathrm{M}$ arsenic with hCGtreated group. Note the increase in number of germ cells with positiveTUNEL labeling. Bars, $20 \mu \mathrm{m}$.

steroidogenic enzyme activity. Our findings demonstrate that low doses of arsenic significantly inhibit progesterone synthesis from pregnenolone, which is a similar trend to that observed for the effects of low doses of arsenic on 11-KT synthesis, except that a significant difference was also found at $1 \mu \mathrm{M}$ of arsenic. It is known that HSD3B is the enzyme that catalyzes the conversion of pregnenolone to progesterone, and other $\Delta^{5}$-3 $\beta$-hydroxysteroids to $\Delta^{4}$-3 ketosteroids, an essential step in the biosynthesis of all biologically active steroids (Keeney et al. 1993) including 11-KT, implying that HSD3B activity may be affected by low doses of arsenic.

In contrast to the lowest dose, moderately higher doses $(1-10 \mu \mathrm{M})$ of arsenic seemed to have no significant effect on 11-KT production unlike their significant effect on germ cells proliferation. The reason for these discrepancies is unclear. It has been demonstrated that treatment of 1.25-10 $\mu \mathrm{M}$ arsenite induces an increased expression of TP53, a checkpoint protein in cell cycle progression, in human fibroblast (Yih \& Lee 2000). Activation of TP53 can result in cell cycle arrest (Lane 1998). Also, in human skin fibroblast, moderate doses $(1.25-5 \mu \mathrm{M})$ of arsenic caused chromosomal aberrations and chromosomal loss, and G2 arrest (particularly at a $5 \mu \mathrm{M}$ concentration) via altering levels of the mitotic regulatory proteins, cyclin B1 and CDC2 (Yih et al. 1997). Hence, moderately high sublethal doses of arsenic may directly inhibit mitotic germ cell proliferation via these signal transduction pathways.
Moreover, arsenic at the highest dose induced a considerable decrease in hCG-induced germ cell proliferation. Although hypertrophy of interstitial tissue was observed with the highest dose of arsenic, 11-KT production was not significantly affected. In teleost, $11-K T$ is synthesized by interstitial Leydig cells in testis, which leads to induction of spermatogenesis (Miura et al. 1991a). Hence, our data imply that the effects of the highest dose of arsenic on germ cell proliferation are not via altering steroid production by Leydig cells, but rather may have direct detrimental action on germ cells.

Furthermore, significant germ cell death was also induced at the highest dose of arsenic. TUNEL assay results revealed a positive staining in germ cells of testis exposed to the highest dose of arsenic alone or with hCG. Moreover, numerous germ cells exhibit positive signal in testis exposed to the highest dose of arsenic combined with hCG. These data imply that high doses of arsenic induce germ cell apoptosis especially after induction of spermatogenesis by hCG. Although there is no such report of arsenic-induced germ cell apoptosis in any other teleosts, in the freshwater fish, C. fasciatus, exposure to high dose of arsenic resulted in altered spermatogenesis associated with pyknosis (Shukla \& Pandey 1984). Pyknosis or irreversible condensation of chromatin in the nucleus of a cell is one of the typical and important features of apoptosis (Zamzami \& Kroemer 1999). Previous studies have shown arsenic to induce

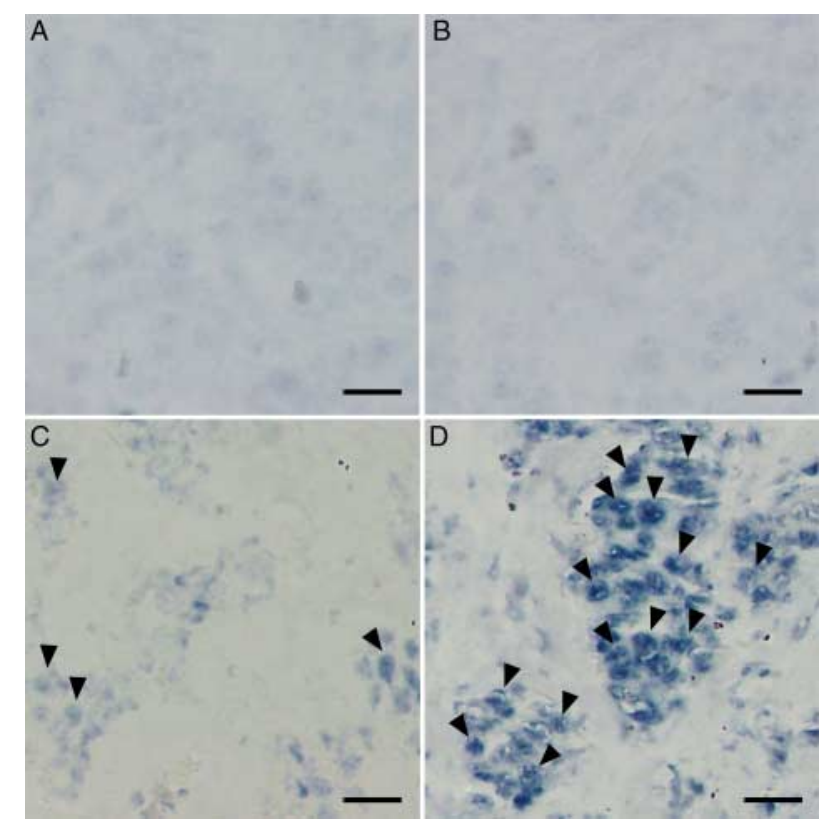

Figure 7 Immunohistochemistry for 8-OHdG in testicular tissue cultured for 3 days in $100 \mu \mathrm{M}$ arsenic alone or $100 \mu \mathrm{M}$ arsenic with hCG. Positively stained germ cells are indicated by arrows. (A) Control. (B) hCG-treated group. No germ cells were stained. (C) $100 \mu \mathrm{M}$ arsenic-treated group. Few germ cells were weakly stained. (D) $100 \mu \mathrm{M}$ arsenic with hCG-treated group. Numerous germ cells showed strong 8 -OHdG positive staining. Bars, $20 \mu \mathrm{m}$. 


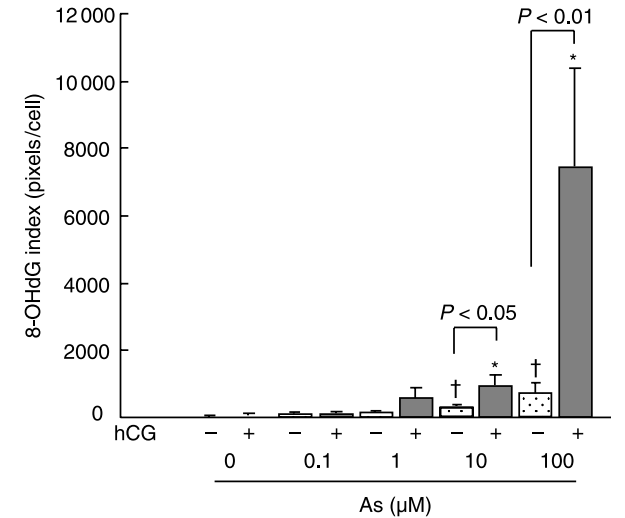

Figure 8 Densitometric quantitation of 8-OHdG immunostaining in arsenic alone and arsenic with hCG-treated testicular fragments. Values are means \pm S.E.M. $(n=5)$. As, arsenic; - , without hCG; + , with hCG. ${ }^{+}$Significantly different from control without hCG $(P<0.05)$. *Significantly different from control with hCG $(P<0.01)$.

apoptosis in hepatocyte cancer cell lines in vitro (Zhang et al. 2003) and in Caenorhabditis elegans germline in vivo (Pei et al. 2008). Moreover, it has also been reported that As(III) causes the release of an apoptosisinducing factor (AIFM1), a flavoprotein that induces apoptosis of isolated nuclei in vitro (Susin et al. 1999), from the mitochondrial intermembrane space that triggers apoptosis (Larochette et al. 1999). In normal human fibroblast, toxic $(50 \mu \mathrm{M})$ concentration of arsenic increased TP53 levels (Vogt \& Rossman 2001), which could initiate apoptosis if the DNA damage is irreparable. Arsenic compounds also have apoptogenic effects on normal cells, e.g. hematopoietic precursors (Wang et al. 1998) and embryonic cells (Mirkes \& Little 1998). Although evidences of arsenic-induced germ cell apoptosis in fish in vivo are limited, our data clearly suggested that high levels of $\mathrm{As}(\mathrm{V})$ considered to be less toxic than As(III) could induce apoptosis in germ cells.

It is known that apoptosis could be induced by oxidative stress (Fiers et al. 1999), and ROS responsible for this stress could induce DNA damage (Takeuchi et al. 1994). 8-OHdG is the most typical among oxidative DNA damage (Kasai \& Nishimura 1986), and has recently been mostly used in mammals as a marker to study DNA damage caused by oxidative stress (Matsui et al. 1999, Toyokuni 1999, Nomoto et al. 2002). To clarify whether oxidative stress is involved in arsenic-induced apoptosis in vitro, we performed immunohistochemistry for 8-OHdG. Our data showed that high-dose arsenic with or without hCG induced DNA damage caused by oxidative stress in germ cells as assessed by $8-\mathrm{OHdG}$ immunostaining. In previous studies in hamster (Liu et al. 2001), human (Pineda-Zavaleta et al. 2004), and fish (Bhattacharya \& Bhattacharya 2007), it is apparent that arsenic induced ROS production, which may consequently cause oxidative damage to DNA, RNA, and proteins. Wang et al. (1996) reported an induction of apoptosis in
Chinese hamster ovary cells concomitant with the increase in intracellular peroxide level. It has also been proposed that oxidative stress induced by arsenic could be responsible for apoptosis (Ercal et al. 2001, Gupta et al. 2003). Interestingly, intense oxidative DNA damage was induced by high doses of arsenic after induction of spermatogenesis by hCG treatment compared to treatment with arsenic alone, which coincide with the TUNEL assay results. Thus, high doses of arsenic induced oxidative stress and caused apoptosis; and proliferating germ cells may be more prone to ROS-induced damage than spermatogonial stem cell. Considering these results, the present study implies that sensitivity to arsenic toxicity and/or ROS induced by arsenic may vary between the different germ cell stages. Although not yet clarified, this variation may be a result of differences in the degree of antioxidant system responses brought by antioxidant enzymes expressed in germ cells. Previous studies have implicated that arsenic modulates the expression of a number of stress proteins such as heat shock proteins in liver and kidney of freshwater teleost, Channa punctatus (Roy \& Bhattacharya 2006), and in human keratinocytes (Deaton et al. 1990), and antioxidant enzymes such as catalase, superoxide dismutase, glutathione-S-transferase, and glutathione peroxidase in liver and kidney of the freshwater teleosts (Allen \& Rana 2003, Bhattacharya \& Bhattacharya 2007). Many of these proteins may play a role in the antioxidant system response against arsenic in eel testis. Further studies are needed to unfold the antioxidant system in testis.

It is concluded that a low dose of arsenic inhibits 11-KT production via suppression of HSD3B activity, which may consequently inhibit spermatogenesis. Moreover, a high dose of arsenic induces germ cell apoptosis mediated by oxidative stress, which induces DNA damage in cells especially during the onset of spermatogenesis induced by hCG. However, the precise mechanism by which moderately high levels $(1-10 \mu \mathrm{M})$ of arsenic inhibit germ cell proliferation remains to be determined. Also, further studies are still needed to elucidate the antioxidant system response of germ cells against arsenic-induced toxicity, which would likely serve as a key to understanding the underlying mechanism of overall arsenic toxicity and provide significant information for establishing a hazard assessment tool for arsenic in fish.

\section{Materials and Methods}

\section{Animals}

Cultivated male Japanese eel, Anguilla japonica (BW: 180$200 \mathrm{~g}$ ), were purchased from a commercial eel supplier and kept in circulating freshwater tanks at $23^{\circ} \mathrm{C}$ until use. The experimental procedures complied with the Guide for Care and Use of Animals at Ehime University. 


\section{Testicular organ culture}

All fish were anesthetized using $0.05 \%(\mathrm{v} / \mathrm{v})$ ethyl-p-amino benzoate before dissection. Testicular organ culture techniques were carried out following Miura et al. (1991a) with minor modifications. Testes from five eels were used in in vitro experiments representing five replicates per treatment. Freshly removed testes were cut into $1 \times 1 \times 0.5 \mathrm{~mm}$ pieces and placed on $1.5 \%(w / v)$ agarose (Agarose S; Wako Inc., Osaka, Japan) cylinders covered with a nitrocellulose membrane in 24-well plastic tissue culture dishes. Testicular fragments $(n=2-4)$ from each fish were randomly assigned to each control and treatment group and then cultured in $1 \mathrm{ml}$ of Leibovitz's L-15 medium (Invitrogen, Ltd) containing $10 \mathrm{mM}$ HEPES, $1.7 \mathrm{mM}$ L-proline, $0.1 \mathrm{mM}$ L-aspartic acid, $0.1 \mathrm{mM}$ L-glutamic acid, $0.5 \%(\mathrm{w} / \mathrm{v}) \mathrm{BSA}$, and $1 \mathrm{mg} / \mathrm{l}$ bovine insulin with $0,0.1,1,10$, and $100 \mu \mathrm{M}$ of arsenic $\left(\mathrm{Na}_{2} \mathrm{HAsO}_{4}\right)$ and/or $0.05 \mathrm{IU} / \mathrm{ml}$ of hCG for 6 or 15 days at $20^{\circ} \mathrm{C}$ in humidified air. The concentrations of arsenic used were based on the previous data from monitoring research in Vietnam (Yamaguchi et al. 2007). For 15 day cultures, the medium was changed on day 7 . Testicular fragments were then fixed in Bouin's solution and cut into $4 \mu \mathrm{m}$ serial paraffin sections and stained with Delafield's hematoxylin-eosin for histological analysis. Two to three slides per fragment and four to six sections per treatment in each slide were analyzed.

\section{Cell proliferation assay}

To analyze proliferation of germ cells, immunohistochemistry for BrdU (Amersham Pharmacia Biotech) incorporated into replicating DNA was performed. After 6 and 15 days of culture, testicular fragments were labeled with a 1:1000 dilution of BrdU for $18 \mathrm{~h}$ and fixed in Bouin's solution. Fixed testicular fragments were embedded in paraffin, cut into $4 \mu \mathrm{m}$ sections, and stained immunohistochemically by anti-BrdU antibody. The sections were counterstained by Delafield's hematoxylin. The number of BrdU-positive germ cells was counted and expressed as percentage of the total number of germ cells in an area comprising of 100-250 germ cells.

\section{In vitro 11-KT synthesis and steroidogenic enzyme activity assay}

Testes removed from the eel's $(n=5)$ body cavity were placed into eel Ringer's solution and cut into small pieces. Afterwards, these fragments (25-50 mg per treatment) were incubated with $1 \mathrm{IU} / \mathrm{ml}$ of hCG with or without $0.0001-$ $100 \mu \mathrm{M}$ of arsenic in Ringer's solution in 24-well plastic plates for $18 \mathrm{~h}$ at $20^{\circ} \mathrm{C}$ with shaking. Five eels used in this experiment represent five replicates per treatment. This incubation experiment was then repeated at least three times on separate occasions. 11-KT in Ringer's solution was extracted with diethyl ether and dissolved in assay buffer. The concentrations of 11-KT in Ringer's solution were then measured by time-resolved fluorescent immunoassay following Yamada et al. (1999) with minor modifications. In brief, $0.05 \mu \mathrm{g} / \mathrm{l}$ of KT-3-(O-carboxymethyl) oxime-bovine serum albumin (KT-3-CMO-BSA, Steraloids Inc., Wilton,
$\mathrm{NH}$, USA) in sodium carbonate buffer ( $\mathrm{pH}$ 9.3) was immobilized to the wells of 96-well plate and allowed to stand at $4{ }^{\circ} \mathrm{C}$ overnight. After three washes with $0.1 \%(\mathrm{w} / \mathrm{v})$ saline containing $0.05 \%(\mathrm{w} / \mathrm{v}) \mathrm{NaN}_{3}$, the plate was blocked with $0.1 \%(\mathrm{w} / \mathrm{v})$ BSA in $0.05 \mathrm{M} \mathrm{Na}_{2} \mathrm{HPO}_{4}$ containing $3 \%$ $(\mathrm{w} / \mathrm{v})$ sucrose and $0.05 \%(\mathrm{w} / \mathrm{v}) \mathrm{NaN}_{3}$ for $2-3 \mathrm{~h}$ at room temperature. The blocking solution was discarded before $50 \mu \mathrm{l}$ standard or sample, and $150 \mu \mathrm{l}$ anti-11-KT antibody in the assay buffer were dispensed to the wells, followed by shaking at $4{ }^{\circ} \mathrm{C}$ overnight. After three washes, $200 \mu \mathrm{l}$ europium (Eu)-labeled goat anti-rabbit IgG was added, and the plate was shaken for $2 \mathrm{~h}$ at room temperature, followed by three washes to remove the excess amount of Eu-labeled IgG. Eu was dissociated from the Eu-labeled IgG bound to the antigen-antibody complex by the addition of $200 \mu \mathrm{l}$ DELFIA enhancement solution (Perkin Elmer Life Sciences, Turku, Finland). The plate was shaken for $5 \mathrm{~min}$ at room temperature, and $\mathrm{Eu}$ fluorescence was measured with a time-resolved fluorometer (ARVO MX 1420, Perkin Elmer).

In order to clarify the mechanism involved in low-dose arsenic effects on 11-KT synthesis, testicular fragments (25-50 mg per treatment) of five eels (as five replicates) were incubated with different steroid hormone precursors, i.e. pregnenolone, progesterone, $17 \alpha$-hydroxyprogesterone, $17 \alpha$ hydroxypregnenolone, androstenedione, testosterone, and $11 \beta$ - hydroxytestosterone at $100 \mathrm{ng} / \mathrm{ml}$ and $1 \mathrm{IU} / \mathrm{ml} \mathrm{hCG}$ with or without arsenic $(0.1-1 \mu \mathrm{M})$ in eel ringer for $18 \mathrm{~h}$ at $20^{\circ} \mathrm{C}$. The steroid levels were then measured similarly with the method described above for 11-KT. The inter- and intra-assay coefficient of variation (CV) were determined using serum samples from eels $(n=10)$. The intra- and inter-assay CV were 9.4 and $10.3 \%$ respectively for $11-\mathrm{KT}$, and 9.55 and $17.4 \%$ respectively for progesterone.

\section{Analysis of germ cell death}

To determine whether arsenic induces apoptosis, testicular fragments from five eels were cultured in vitro as described above for 3 days in $1 \mathrm{ml}$ of Leibovitz's L-15 medium. After culture, the fragments were fixed in Bouin's solution and embedded in paraffin. TUNEL assay was then conducted on 5 - $\mu$ m-thick serial sections following the manufacturer's protocol (In Situ Cell Death Detection Kit, POD; Roche Diagnostics). For positive control, sections were treated with $600 \mathrm{U} / \mathrm{ml}$ DNAse I (Takara Bio Inc., Shiga, Japan) prior to TUNEL assay.

\section{Immunohistochemistry for 8-OHdG}

Immunohistochemistry for $8-\mathrm{OHdG}$ using anti-8-OHdG MAB (Japan Institute for the Control of Aging, Shizuoka, Japan) was performed on serial sections of testicular tissue used for TUNEL to investigate oxidative stress in testis following the manufacturer's protocol with some modifications. After deparaffinization and rehydration, the sections were microwave heated in $10 \mathrm{mM}$ citric acid buffer ( $\mathrm{pH}$ 6.0). The sections were then blocked in 1\% (w/v) DIG-blocking reagent (Roche Diagnostics) in PBS pH 7.4 for $30 \mathrm{~min}$ at room temperature, and the primary antibody was added and incubated at 
$4{ }^{\circ} \mathrm{C}$ overnight. Biotin-labeled rabbit anti-mouse IgG was used as the secondary antibody, followed by a streptavidinalkaline phosphatase complex (Nichirei Biosciences Inc., Tokyo, Japan).

\section{Quantitation of 8-OHdG immunostaining}

The following formula was used for the densitometric quantitation of $8-\mathrm{OHdG}$ immunohistochemistry $(8-\mathrm{OHdG}$ index), as previously described (Toyokuni 1999):

8-OHdG index $=\Sigma((X-$ threshold $)$

$$
\times \text { area (pixels))/total cell number }
$$

where $X$ is the staining density indicated by a number between 0 and 256 in grayscale, and $X$ is more than the threshold. Cell numbers were determined using the Analyze Particle command after setting a proper threshold. To determine the integrated density of each file, a density slice between 100 and 256 pixels was selected for the measurement command. Mean values of the integrated density per cells, which were obtained from two independently obtained files, were used as the representative value for ' 8 -OHdG index'. The brightness of each image file was uniformly enhanced by Adobe Photoshop software (Adobe Systems Inc.), followed by analysis using National Institutes of Health $(\mathrm{NIH})$ image freeware, which is available on the Internet via file transfer protocol from zippy.nimh.nih.gov.

\section{Statistical analysis}

All values were expressed as mean \pm s.E.M. A one-way ANOVA followed by Tukey's multicomparison test was used to analyze the differences of means using KaleidaGraph statistical software (Synergy Software, Reading, PA, USA). Significant difference was accepted at $P<0.05$ in all cases unless indicated.

\section{Declaration of interest}

The authors declare that there is no conflict of interest that would prejudice the impartiality of this scientific work.

\section{Funding}

This study was supported by Grant-in-Aid for Young Scientists 2007 by Global COE Program from the Japan Society for the Promotion of Science (JSPS) (to F T C).

\section{Acknowledgements}

We thank Mr Richard Hanna (East Carolina University, USA) for critically reading an early draft of this manuscript.

\section{References}

Ahmad I, Khalid TH \& Akthar M 2008 Arsenic induced microscopic changes in rat testis. Professional Medical Journal 15 287-291.
Alam MB, Allinson G, Stagnathi F, Tanaka A \& Westbrooke M 2002 Arsenic contamination in Bangladesh groundwater: a major environmental and social disaster. International Journal of Environmental Research and Public Health 12 236-253.

Allen T \& Rana VS 2003 Effect of arsenic (As $\left.{ }^{\text {III }}\right)$ on gluthathione-dependent enzymes in liver and kidney of the freshwater fish Channa punctatus. Biological Trace Element Research 100 39-48.

Bhattacharya A \& Bhattacharya S 2007 Induction of oxidative stress by arsenic in Clarias batrachus: involvement of peroxisomes. Ecotoxicology and Environmental Safety 66 178-187.

Bodwell JE, Kingsley LA \& Hamilton JW 2004 Arsenic at very low concentrations alters glucocorticoid receptor (GR)-mediated gene activation but not GR-mediated gene repression: complex doseresponse effects are closely correlated with levels of activated GR and require a functional GR DNA binding domain. Chemical Research in Toxicology 17 1064-1076.

Bodwell JE, Gosse JA, Nomikos AP \& Hamilton JW 2006 Arsenic disruption of steroid receptor gene activation: complex dose-response effects are shared by several steroid receptors. Chemical Research in Toxicology 19 1619-1629.

Borg B 1994 Androgens in teleost fishes. Comparative Biochemistry and Physiology. Part C, Pharmacology, Toxicology \& Endocrinology 109 219-245.

Cullen WR \& Reimer KJ 1989 Arsenic speciation in the environment. Chemical Reviews 89 713-764.

Davey JC, Bodwell JE, Gosse JA \& Hamilton JW 2007 Arsenic as an endocrine disruptor: effects of arsenic on estrogen receptor-mediated gene expression in vivo and in cell culture. Toxicological Sciences 98 75-86.

Deaton MA, Bowman PD, Jones GP \& Powanda MC 1990 Stress protein synthesis in human keratinocytes treated with sodium arsenite, phenyldichloroarsine, and nitrogen mustard. Fundamental and Applied Toxicology 14 471-476.

Duker AA, Carranza EJM \& Hale M 2005 Arsenic geochemistry and health. Environment International 31 631-641.

Ercal N, Gurer-Orhan H \& Aykin-Burns N 2001 Toxic metals and oxidative stress Part I: mechanisms involved in metal-induced oxidative damage. Current Topics in Medicinal Chemistry 1 529-539.

Fiers W, Beyaert R, Declerq W \& Vandenabeele P 1999 More than one way to die: apoptosis, necrosis and reactive oxygen damage. Oncogene $\mathbf{1 8}$ 7719-7730.

Gupta S, Yel L, Kim D, Kim C, Chiplunkar S \& Gollapudi S 2003 Arsenic trioxide induces apoptosis in peripheral blood $\mathrm{T}$ lymphocyte subsets by inducing oxidative stress: a role of $\mathrm{BCl}-2$. Molecular Cancer Therapeutics $2711-719$.

Kaltreider RC, Davis AM, Lariviere JP \& Hamilton JW 2001 Arsenic alters the function of the glucocorticoid receptor as a transcription factor. Environmental Health Perspectives 109 245-251.

Kasai H \& Nishimura S 1986 Hydroxylation of guanine in nucleosides and DNA at the C-8 position by heated glucose and oxygen radical-forming agents. Environmental Health Perspectives 67 111-116.

Keeney DS, Naville D, Milewich L, Bartke A \& Mason JI 1993 Multiple isoforms of $3 \beta$-hydroxysteroid dehydrogenase $/ \Delta^{5}-\Delta^{4}$ isomerase in mouse tissues: male-specific isoforms are expressed in the gonads and liver. Endocrinology 133 39-45.

Kubota R, Kunito T \& Tanabe S 2002 Speciation of arsenic in the livers of higher trophic marine animals. Marine Pollution Bulletin 45 218-223.

Lane D 1998 Cancer: awakening angels. Nature 394 616-617.

Larochette N, Decaudin D, Jacotot E, Brenner C, Marzo I, Susin SA, Zamzami N, Xie Z, Reed J \& Kroemer G 1999 Arsenite induces apoptosis via a direct effect on the mitochondrial permeability transition pore. Experimental Cell Research 249 413-421.

Liu SX, Athar M, Lippai I, Waldren C \& Hei TK 2001 Induction of oxyradicals by arsenic: implication of genotoxicity. PNAS $\mathbf{9 8}$ 1643-1648.

Matsui M, Nishigori C, Toyokuni S, Takada J, Akaboshi M, Ishikawa M, Imamura S \& Miyachi Y 1999 The role of oxidative DNA damage in human arsenic carcinogenesis: detection of 8-hydroxy-2'-deoxyguanosine in arsenic-related Bowen's disease. Journal of Investigative Dermatology 113 26-31. 
Mirkes PE \& Little SA 1998 Teratogen-induced cell death in postimplantation mouse embryos: differential tissue sensitivity and hallmarks of apoptosis. Cell Death and Differentiation 5 592-600.

Miura T \& Miura C 2003 Molecular control mechanisms of fish spermatogenesis. Fish Physiology and Biochemistry 28 181-186.

Miura T, Yamauchi K, Takahashi H \& Nagahama Y 1991a Hormonal induction of all stages of spermatogenesis in vitro in the male Japanese eel (Anguilla japonica). PNAS 88 5774-5778.

Miura T, Yamauchi K, Takahashi H \& Nagahama Y $1991 b$ Induction of spermatogenesis in male Japanese eel, Anguilla japonica, by a single injection of human chorionic gonadotropin. Zoological Science 8 63-73.

Miura C, Takahashi N, Michino F \& Miura T 2005 The effects of paranonylphenol on Japanese eel (Anguilla japonica) spermatogenesis in vitro. Aquatic Toxicology 71 133-141.

Miura T, Higuchi M, Ozaki Y, Ohta T \& Miura C 2006 Progestin is an essential factor for the initiation of the meiosis in spermatogenetic cells of the eel. PNAS 103 7333-7338.

Mukherjee A, Sengupta MK, Hossain MA, Ahamed S, Das B, Nayak B, Lodh D, Rahman MM \& Chakraborti D 2006 Arsenic contamination in groundwater: a global perspective with emphasis on the Asian scenario. Journal of Health, Population, and Nutrition 24 142-163.

Nomoto T, Nishina T, Miwa S, Tsuneyoshi H, Maruyama I, Nishimura K \& Komeda M 2002 Angiotensin-converting enzyme inhibitor helps prevent late remodeling after left ventricular aneurysm repair in rats. Circulation 106 115-119.

Ozaki Y, Higuchi M, Miura C, Yamaguchi S, Tozawa Y \& Miura T 2006 Roles of $11 \beta$-hydroxysteroid dehydrogenase in fish spermatogenesis. Endocrinology 147 5139-5146.

Pant N, Kumar R, Murthy RC \& Srivastava SP 2001 Male reproductive effect of arsenic in mice. Biometals 14 113-117.

Pei B, Wang S, Guo X, Wang J, Yang G, Hang H \& Wu L 2008 Arseniteinduced germline apoptosis through a MAPK-dependent, p53-independent pathway in Caenorhabditis elegans. Chemical Research in Toxicology 21 1530-1535.

Pineda-Zavaleta AP, Garcia-Vargas G, Borja-Aburto VH, AcostaSaavedra LC, Vera Aguilar E, Gomez-Muñoz A, Cebrian ME \& Calderon-Aranda ES 2004 Nitric oxide and superoxide anion production in monocytes from children exposed to arsenic and lead in region Lagunera, Mexico. Toxicology and Applied Pharmacology 198 283-290.

Roy S \& Bhattacharya S 2006 Arsenic-induced hispathology and synthesis of stress proteins in liver and kidney of Channa punctatus. Ecotoxicology and Environmental Safety 65 218-229.

Sarkar M, Biswas NM \& Ghosh D 1991 Effect of sodium arsenite on testicular $\Delta^{5}-3 \beta$ and $17 \beta$-hydroxysteroid dehydrogenase activities in albino rats: dose- and duration-dependent responses. Medical Science Research 19 789-790.

Shukla JP \& Pandey K 1984 Impaired spermatogenesis in arsenic treated freshwater fish, Colisa fasciatus (Bl. and Sch.). Toxicology Letters 21 191-195.

Smedley PL \& Kinniburgh DG 2002 A review of the source, behaviour and distribution of arsenic in natural waters. Applied Geochemistry 17 517-568.
Susin SA, Lorenzo HK, Zamzami N, Marzo I, Snow BE, Brothers GM, Mangion J, Jacotot E, Costantini P, Loeffler M et al. 1999 Molecular characterization of mitochondrial apoptosis-inducing factor (AIF). Nature 397 441-446.

Takeuchi T, Nakajima M \& Morimoto K 1994 Establishment of a human system that generates $\mathrm{O}_{2}^{-}$and induces 8-hydroxydeoxyguanosine, typical of oxidative DNA damage, by a tumor promoter. Cancer Research $\mathbf{5 4}$ 5837-5840.

Toyokuni S 1999 Reactive oxygen species-induced molecular damage and its application in pathology. Pathology International 49 91-102.

Vogt BL \& Rossman TG 2001 Effects of arsenite on p53, p21 and cyclin D expression in normal human fibroblasts - a possible mechanism for arsenite's comutagenicity. Mutation Research 478 159-168.

Wang T, Kuo C, Jan K \& Huang H 1996 Arsenite induces apoptosis in Chinese hamster ovary cells by generation of reactive oxygen species. Journal of Cellular Physiology 169 256-268.

Wang ZG, Rivi R, Delva L, Konig A, Scheinberg DA, GambacortiPasserini C, Gabrilove JL, Warrell RP \& Pandolfi PP 1998 Arsenic trioxide and melarsoprol induce programmed cell death in myeloid leukemic cell lines and function in a PML and PML-RAR $\alpha$ independent manner. Blood 92 1497-1504.

WHO 1996 Guidelines for Drinking-Water Quality, edn 2, p 7. Geneva: World Health Organization.

Yamada H, Satoh R, Yamashita T, Kambegawa A \& Iwata M 1999 Development of a time-resolved fluoroimmunoassay (TR-FIA) for testosterone: measurement of serum testosterone concentrations after testosterone treatment in the rainbow trout (Oncorhynchus mykiss). General and Comparative Endocrinology 106 181-188.

Yamaguchi S, Miura C, Ito A, Agusa T, Iwata H, Tanabe S, Tuyen BC \& Miura T 2007 Effects of lead, molybdenum, rubidium, arsenic and organochlorines on spermatogenesis in fish: monitoring at Mekong Delta area and in vitro experiment. Aquatic Toxicology 83 43-51.

Yih LH \& Lee TC 2000 Arsenite induces p53 accumulation through an ATMdependent pathway in human fibroblasts. Cancer Research 60 6346-6352.

Yih LH, Ho IC \& Lee TC 1997 Sodium arsenite disturbs mitosis and induces chromosome loss in human fibroblasts. Cancer Research 57 5051-5059.

Zamzami N \& Kroemer G 1999 Apoptosis: condensed matter in cell death. Nature 401127.

Zhang T, Wang SS, Hong L, Wang XL \& Qi QH 2003 Arsenic trioxide induces apoptosis of rat hepatocellular carcinoma cells in vivo. Journal of Experimental \& Clinical Cancer Research 22 1-8.

Received 26 April 2009

First decision 20 May 2009

Revised manuscript received 22 May 2009

Accepted 2 June 2009 